\title{
Classed attitudes and social reform in cross-national perspective: a quantitative analysis using four waves from the International Social Survey Programme (ISSP)
}

Christopher Deeming

\begin{abstract}
This article attempts to forge new links between social attitudes and social policy change in Australia. Drawing on four survey waves of international social survey data and using multivariate regression analysis, this article sheds new light on the determinants of Australian attitudes towards the welfare state. It examines their variations across time and compares them with other leading Western economies. While there is popular support for government actions to protect Australian citizens in old age and sickness, views about social protection and labour market policy for the working-age population are divided. The comparative analysis and the focus on class-attitude linkages allows for further critical reflection on the nature of social relations and recent social reforms enacted by the Liberal-National coalition government.
\end{abstract}

Keywords class, data analysis, political sociology, quantitative analysis, welfare state

\section{Introduction}

Much recent writing about social reform in the Australian context overlooks the importance of social attitudes that may help to explain change. However, linking people's values and attitudes with social reform is a complex but altogether necessary endeavour if we are to understand more about how the modern state is being transformed. Much of the early work on welfare state development points to class politics, and working-class solidarities in 
particular, as crucial factors influencing social policies (Castles, 1985; Esping-Andersen, 1990). At the start of the twenty-first century, however, we now understand that individualizing and liberalizing market processes everywhere may be eroding important aspects of social solidarity; once distinctive welfare states may be losing their particularity under the weight of recent market reforms. This article therefore aims to forge new linkages between public opinion and social change in the Australian context.

The analysis is supported by data on comparative welfare attitudes from the International Social Survey Programme (ISSP) (Haller et al., 2012). Using multivariate regression techniques, we consider Australian preferences for risk protection. We are particularly interested in comparing Australian welfare state attitudes with views found elsewhere, but we are also interested in social attitudes defined by socio-demographic characteristics including 'class' effects in the data (here 'social class' is defined by the Erikson-Goldthorpe-Portocarero (EGP) class scheme, see Leiulfsrud et al., 2010). In the analysis, we rely on all four waves of the ISSP Role of Government (RoG) module for our sample of leading Western economies that includes Australia. The time span is a twenty-year period and the total country-wave sample comprises over 43,000 records. Before describing the study methods and results and discussing their implications, we consider the scholarship that discusses the links between welfare state attitudes and social policy development.

\section{Theoretical perspectives}

Esping-Andersen argues that, according to the logic of industrialism, the 'welfare state' was a functional response to working-class mobilization (in political parties and unions) and the needs of industrial capitalist society (Esping-Andersen, 1990). Welfare states secured 
citizens against risk. Their objective was to protect (by guaranteeing a substitute income) male breadwinner wages from the social risks of the day: unemployment, sickness and old age. Although social welfare systems (comprising health, pensions and social security provisions) differed across the industrial nations - suggesting national traditions and cultural factors at play - nevertheless, the emphasis of social policy was placed on full employment (following Keynesian principles) and the protection of working-class families within the capitalist state. In the liberal market economies of Australia and New Zealand, for example, social protection was largely delivered through a family wage policy (Castles, 1985). In the United States, targeted social welfare programs expanded under the New Deal, while in Britain, the 'Beveridgean' tax-financed welfare state offered a needs-based and means-tested safety net. Australia, New Zealand, the USA, and the UK are said to conform more to the 'liberal' model of welfare capitalism (Esping-Andersen, 1990), in the sense that this model represents strong elements of individualism, opposition to state intervention, marketization and the commodification of labour. In Continental Europe, 'societal corporatism' emerged out of industrialization, with 'Bismarkian' systems of worker insurance and company-based social protection schemes in France and Germany. In Scandinavia, Social Democratic governments in the pursuit of equality developed the universal model of 'welfare capitalism' - a broad sense of 'solidarity' (with middle-class support) - came much more easily in the Nordic nations than did either individualism or corporatism, as Esping-Andersen (1990) observes.

As Svallfors (2006) suggests, welfare states may foster and promote social solidarity and they may also reflect it (or the lack of it). Thus, if welfare states have a tendency to produce and reproduce their own legitimacy, from a comparative policy perspective, we might therefore expect welfare attitudes to diverge across the advanced societies, to reflect - at least in part - dominant welfare state ideology. As our point of departure, we might assume that 
there is regime-related variation in welfare attitudes in the international social survey data. As previous research suggests, people in the Nordic world tend to be most favourable to government action, while people in liberal market economies are significantly less favourable towards governmental action than people in the Bismarkian nations of Europe (e.g. Svallfors, 1997; Jæger, 2011). However, it does not automatically follow that all Australian citizens stand against state actions or particular governmental programmes. Further, scholars now argue that once distinctive welfare regime types are losing their distinctiveness under the weight of reform. Today's diverse, multi-faceted welfare systems often challenge straightforward typologies and policymakers in the Bismarkian and Nordic countries are now turning to characteristically market liberal activation measures to increase labour market entry (Lodemel and Moreira, 2014). Institutional differences remain (there are different 'activation' and 'workfare' regimes, as shown in Table 1). However, attitudinal cleavages, once clearly visible between the worlds of welfare, may soften and diminish with the arrival of activation policies everywhere. In Australia, for example, 'jobseekers' are now obliged to undertake work commitments in exchange for access to social benefits under Tony Abbott's new 'workfare' regime. 
Table 1. Worlds of 'welfare' and varieties of 'workfare'

\begin{tabular}{|c|c|c|c|}
\hline & $\begin{array}{l}\text { Corporatist welfare } \\
\text { states }\end{array}$ & $\begin{array}{l}\text { Liberal welfare } \\
\text { states }\end{array}$ & $\begin{array}{l}\text { Social-democratic } \\
\text { welfare states }\end{array}$ \\
\hline & \multicolumn{3}{|c|}{ Welfare strategies } \\
\hline Orientation & $\begin{array}{l}\text { Social protection, } \\
\text { stabilization. }\end{array}$ & Market-orientated. & $\begin{array}{l}\text { Social citizenship and } \\
\text { pursuit of equality. }\end{array}$ \\
\hline Welfare model & $\begin{array}{l}\text { Categorical design of } \\
\text { social programs and } \\
\text { corporatist labour- } \\
\text { market relations. }\end{array}$ & $\begin{array}{l}\text { Means-tested and } \\
\text { residual assistance. }\end{array}$ & $\begin{array}{l}\text { Universal programs } \\
\text { and fusion of } \\
\text { welfare/work. }\end{array}$ \\
\hline $\begin{array}{l}\text { Labour-market } \\
\text { policy }\end{array}$ & $\begin{array}{l}\text { Active, geared to rise } \\
\text { in unemployment. }\end{array}$ & $\begin{array}{l}\text { Passive income } \\
\text { support. }\end{array}$ & $\begin{array}{l}\text { Active, geared towards } \\
\text { social investment. }\end{array}$ \\
\hline \multirow[t]{2}{*}{ Ideology } & $\begin{array}{l}\text { Corporatism and status } \\
\text { based rights. }\end{array}$ & $\begin{array}{l}\text { Market individualist } \\
\text { problematisation, } \\
\text { stigmatization of } \\
\text { welfare. }\end{array}$ & $\begin{array}{l}\text { Universal rights and } \\
\text { shared responsibilities, } \\
\text { positive welfare } \\
\text { orientation. }\end{array}$ \\
\hline & \multicolumn{3}{|c|}{ Workfare strategies } \\
\hline Orientation & $\begin{array}{l}\text { Statist, emphasis on } \\
\text { skilling and tackling } \\
\text { structural } \\
\text { unemployment. }\end{array}$ & $\begin{array}{l}\text { Market individualist, } \\
\text { emphasis on work- } \\
\text { conditionality to } \\
\text { counter 'welfare } \\
\text { dependency'. }\end{array}$ & $\begin{array}{l}\text { Social, labour-market } \\
\text { adjustments. }\end{array}$ \\
\hline Workfare model & $\begin{array}{l}\text { Labour-market } \\
\text { reintegration, active } \\
\text { labour market policies } \\
\text { and stricter activation } \\
\text { measures. }\end{array}$ & $\begin{array}{l}\text { 'Work-first' (any job } \\
\text { is better than } \\
\text { inactivity) and } \\
\text { restriction of welfare } \\
\text { entitlements with } \\
\text { increased work- } \\
\text { conditionality. }\end{array}$ & $\begin{array}{l}\text { Human-capital } \\
\text { approach and } \\
\text { investment and } \\
\text { increased welfare- } \\
\text { conditionality }\end{array}$ \\
\hline Ideology & $\begin{array}{l}\text { Work values with } \\
\text { continuing } \\
\text { commitment to status } \\
\text { based rights. }\end{array}$ & $\begin{array}{l}\text { Moral regulation, } \\
\text { work ethos, discipline } \\
\text { and social control. }\end{array}$ & $\begin{array}{l}\text { Structural } \\
\text { reorientation of } \\
\text { welfarist approach. }\end{array}$ \\
\hline
\end{tabular}

Source: Adapted from Lodemel and Moreira (2014).

Welfare state attitudes often vary within countries, depending on the sphere of welfare provision in question. Some social groups in society are perceived as more deserving than others (Papadakis, 1990; Jæger, 2007). For example, older people are traditionally perceived to be more deserving than unemployed people are. There are also socioeconomic correlates between different types of welfare attitudes. Previous research suggests that working-class representatives are more likely to support governmental interventions compared to middleclass representatives, particularly with regard to statutory interventions in case of sickness and old age (e.g. Svallfors, 2006; Jæger, 2007). However, we know little about solidarity and class-welfare relations within the Australian context. As the Australian system of welfare is 
transformed to encourage greater labour market participation, we need to ask: will social cleavages become more pronounced or less? Labour market flexibility and non-standard employment have meant increased insecurity for many Australians. Under these circumstances, we might expect class awareness and solidarity to increase, as writers like Curran (2013) suggest. From this perspective, working-class citizens in Australia are more likely than middle-class citizens to support welfare state and governmental programmes that safeguard their interests, particularly full employment policies and social policies that protect their living standards in the event unemployment, as well as social policies that offer protection against poverty in old age.

On the other hand, once firm politically oriented allegiances have become less secure in modern societies, class cleavages may diminish. The working class is said to be in decline with the loss of industry and notions of 'class struggle' (as opposition between capital and labour) now appear to be less apparent in political life (Beck and Grande, 2010). A new space has opened up for individuals in search of 'individualized' lifestyles. This is part of the process of 'individualization', with civic institutions now tailored to individual concerns. New solidarities may emerge or become significant in response to 'risk society', to do with age, gender, education or religion (Beck and Grande, 2010). Religious and ethnic views may become relevant, insofar as they may divide or weaken traditional class-based forms of welfare solidarity. Cultural and political liberalism, for instance, have been linked to the rise of the professional class. Higher education, which has expanded beyond recognition, is also associated with liberal values and individualism. Crucially, the 'legitimacy' of governmental interventions may depend on the continued support of middle-class citizens, as Svallfors (2006) argues. With the extension of individualistic and market-orientated welfare arrangements, however, their support cannot be taken for granted. Arguably, the new activation measures are designed to foster adaptability whereby more affluent citizens seek to 
minimize their own exposure to risk, at the expense of risk pooling, as Keune and Serrano (2014) observe.

In order to understand the trajectory of Australian social reform in a comparative fashion, we examine changing public attitudes towards risk and welfare protection in Australia and other leading Western economies over the last twenty years. However, if we are to shed further light on recent social reforms and their political impacts, we also require a more comprehensive understanding of (changing) solidarities in Australia defined by traditional indictors of welfare allegiance, such as partisanship and class (plus class-related factors, such as income and education).

\section{Methods}

The comparative welfare analysis reported here relies heavily on survey data from all four rounds of the ISSP RoG: wave I-IV conducted in 1985, 1990, 1996 and 2006 (ISSP Research Group, 2008). The ISSP is an important international social survey collaboration providing cross-national and cross-cultural perspectives on key research topics in the social sciences (Haller et al., 2012). It follows a repeated cross-sectional survey design and employs sampling procedures in an attempt to ensure that views are nationally representative of all individuals aged over fifteen years who reside within private households in the participating countries. In the analysis, we are interested in situating Australian welfare state attitudes in a comparative context, across time and national policy contexts, and we are interested in social attitudes defined by socio-demographic characteristics including class. The time span is a twenty-year period and the total country-wave sample comprises over 43,000 respondents (see Table 2). 
Table 2. Country-wave study sample

\begin{tabular}{|c|c|c|c|c|c|}
\hline & $\begin{array}{l}\text { Wave I } \\
\text { (1985) }\end{array}$ & $\begin{array}{l}\text { Wave II } \\
\text { (1990) }\end{array}$ & $\begin{array}{c}\text { Wave III } \\
\text { (1996) }\end{array}$ & $\begin{array}{c}\text { Wave IV } \\
\text { (2006) }\end{array}$ & Totals \\
\hline Australia (AUS) & 1,528 & 2,398 & 2,151 & 2,781 & 8,858 \\
\hline Denmark (DNK) & - & - & - & 1,368 & 1,368 \\
\hline Finland (FIN) & - & - & - & 1,189 & 1,189 \\
\hline France (FRA) & - & - & 1,312 & 1,824 & 3,136 \\
\hline Germany $(\mathrm{DEU})^{\alpha}$ & 1,048 & 3,840 & 3,470 & 1,643 & 10,001 \\
\hline New Zealand (NZL) & - & - & 1,198 & 1,263 & 2,461 \\
\hline Norway (NOR) & - & 1,517 & 1,344 & 1,330 & 4,191 \\
\hline Sweden (SWE) & - & - & 1,238 & 1,194 & 2,432 \\
\hline United Kingdom (GBR) & 1,530 & 1,197 & 989 & 930 & 4,646 \\
\hline United States (USA) & 677 & 1,217 & 1,332 & 1,518 & 4,744 \\
\hline Totals & 4,783 & 10,169 & 13,034 & 15,040 & 43,026 \\
\hline
\end{tabular}

Source: International Social Survey Programme (ISSP) Role of Government (RoG) I-IV (ISSP Research Group, 2008).

Notes: ${ }^{\alpha}$ Wave I covered West Germany only, from Wave II Germany (inc. East).

The RoG module asks respondents a series of questions about preferences for risk protection across different social welfare functions and different population groups. For example, respondents were asked whether it should or should not be the government's responsibility to do the following:

- provide healthcare for the sick;

- provide a decent standard of living for old people;

- provide a decent standard of living for unemployed people; and

- provide a job for everyone.

The respondents' opinions on these four questions is the object of our analysis. The response categories were 'definitely should be', 'probably should be', 'probably should not be', 'definitely should not be' and 'can't choose'. The dependent variables were constructed from the four questions, responses being binary coded into positive (definitely should, probably should) and negative (definitely should not, probably should not) attitudes towards the welfare state. The 'can't choose' category was treated as missing data. The explanatory 
variables are 'dummy coded', e.g., female dummy variable, unemployed dummy variable etc., shown in Table 3. In the analysis, the Nordic countries are represented by Denmark, Finland, Norway and Sweden. We include the 'corporatist' countries of France and Germany, and the liberal market economies of Australia, New Zealand, the United Kingdom and the United States.

Table 3. Dependent and independent variables

\begin{tabular}{|c|c|c|}
\hline Variable & Variable label & Specification in the study \\
\hline AGE & Age & $\begin{array}{l}\text { Welfare attitudes may be age related. Age is coded into } 6 \\
\text { groups. }\end{array}$ \\
\hline SEX & Sex & Gender may help to explain social attitudes. \\
\hline DEGREE & Education II-highest education level & $\begin{array}{l}\text { Education attainment, recoded into three categories: 'degree', } \\
\text { 'below degree level', 'no qualifications'. }\end{array}$ \\
\hline WRKST & Current employment status & $\begin{array}{l}\text { Labour force participation coded: 'employed', 'unemployed', } \\
\text { or 'economically inactive' (the latter covering people in } \\
\text { education, retirement, and unpaid family workers'. }\end{array}$ \\
\hline ISCO88 & Occupation ILO/ISCO & $\begin{array}{l}\text { Class is likely to be important. EGP class scheme: } \\
\text { professionals, salaried white-collar employees, skilled manual, } \\
\text { and low-skilled manual workers. }\end{array}$ \\
\hline PARTY_LR & Party affiliation & $\begin{array}{l}\text { Political views are likely to important explanatory variables, } \\
\text { here we consider: left, centre, right affiliation. }\end{array}$ \\
\hline V6 & Country & $\begin{array}{l}\text { United States (USA), United Kingdom (GBR), Australia } \\
\text { (AUS), Germany (DEU), France (FRA), Norway (NOR), New } \\
\text { Zealand (NZL), Sweden (SWE). Denmark and Finland only } \\
\text { participated in the latest survey wave and therefore cannot be } \\
\text { included in the time-variant regression analysis. }\end{array}$ \\
\hline V4 & Wave/Year & $\begin{array}{l}\text { Attitudes may be time-variant. Here we consider changes over } \\
\text { wave III (1996) and IV (2006). Discontinuity with occupation } \\
\text { coding means it is not possible to include the first two survey } \\
\text { waves. }\end{array}$ \\
\hline V50 & $\begin{array}{l}\text { Government responsibility: Provide } \\
\text { jobs for everyone. }\end{array}$ & $\begin{array}{l}\text { Answers of probably and definitely are coded 'yes'; probably } \\
\text { not and definitely not are coded 'no'. }\end{array}$ \\
\hline V52 & Government responsibility: Healthcare & $\begin{array}{l}\text { Answers of probably and definitely are coded 'yes'; probably } \\
\text { not and definitely not are coded 'no'. }\end{array}$ \\
\hline V53 & $\begin{array}{l}\text { Government responsibility: Provide } \\
\text { decent living standard for the old. }\end{array}$ & $\begin{array}{l}\text { Answers of probably and definitely are coded 'yes'; probably } \\
\text { not and definitely not are coded 'no'. }\end{array}$ \\
\hline V55 & $\begin{array}{l}\text { Government responsibility: Provide } \\
\text { decent living standard for unemployed. }\end{array}$ & $\begin{array}{l}\text { Answers of probably and definitely are coded 'yes'; probably } \\
\text { not and definitely not are coded 'no'. }\end{array}$ \\
\hline WEIGHT & Weighting factor & All study calculations are weighted. \\
\hline
\end{tabular}

Source: ISSP Role of Government I-IV (ISSP Research Group, 2008).

While 'social class' is a key variable in the analysis, it remains a deeply contested concept in the social sciences, as Haddon (2014) observes. Here we adopt the standard EGP class scheme that is widely used in international and comparative research, which relies on 
occupational status (Leiulfsrud et al., 2010). EGP classes were created using the SPSSprogram developed by Ganzeboom et al. (1992), based on the ISCO-88 occupational codes available in the latest survey rounds. The class analysis focuses on survey data from waves three and four; fundamental changes to the way occupation is coded means the earlier rounds cannot be included. ${ }^{1}$ According to the theory in question, classes are aggregations of positions within the labour market. Across the whole sample, we observe the following structure: one-third of the working population belong to the professional and higher managerial occupations classes and one-third belong to the 'salariat' (the salaried whitecollar employees). Thirteen percent of the working classes are in skilled manual occupations and seventeen percent are low-skilled workers. The reduction of class to occupation threatens to leave out of the model those citizens who are 'unemployed' (i.e., the benefitdependent group), and those citizens who 'economically inactive' (i.e., people not in work or seeking employment: pensioners and the retired population, students or unpaid family workers and carers). In the analysis, however, other socio-demographic variables are included to produce a multifactoral approach to class and social relations (including labour force status; see Table 3).

We begin with a descriptive overview and analysis of the data before using multivariate logistic regression models for binary outcomes (cf. Hosmer and Lemeshow, 2000) to assess the socio-demographic characteristics that help to explain or predict attitudes to welfare state functions in Australia and the other leading economies. In other words, we are interested in attitudinal differences at the aggregate level, in terms of cross-national and welfare regimerelated variations and effects, as well as the interaction of aggregate level and individual level characteristics captured by the social survey. The odds ratios in the results (Tables 4 and 5) show the strength and the direction of the independent predictors ('independent' here means after taking account of all of the other demographic and socioeconomic variables in the 
model). The R-statistic indicates the proportion of variability in the model and asterisks indicate the level of significance. ${ }^{2}$ Much of the discussion focuses on the multivariate results in Tables 4 and 5, with cross-referencing to the effects for country and class in Table 6. All study calculations are weighted to correct for differential and non-response bias in the survey data.

\section{Results}

In the survey data, we find that there is almost universal support across nations for governmental actions to ensure decent living standards in old age (Figure 1) and healthcare for the sick (Figure 2). In Australia, and even the USA where public support for social welfare is at its lowest, we still find the overwhelming majority of people claiming that these social programmes are functions of good government. The latest survey wave of 2007 revealed that over 90 percent of Australians believe that government intervention in the market is justified to provide a decent standard of living for workers in retirement; over 90 percent of Australians also believe that access to healthcare is a social right. The available survey evidence suggests that Kevin Rudd and Julia Gillard did not misinterpret the nature of support in Australia for better aged pensions and a better healthcare system. Under Labor (2007-2013), the minimum income floor for pensioners was raised against average weekly male earnings and the health service, which had been fragmented on state lines and under different tiers of government, was significantly strengthened with new funding for health and hospital services (National Health and Hospitals Network Act 2011). 
Figure 1. Decent living standard for old people: Percentage claiming it should be the government's responsibility, by country and wave

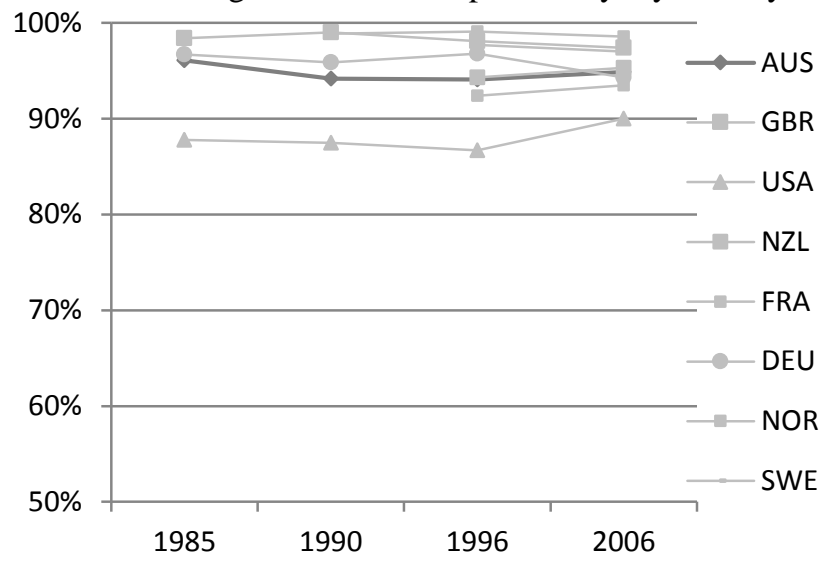

Source: ISSP RoG I-IV (ISSP Research Group, 2008).

Figure 2. Healthcare for the sick: Percentage claiming it should be the government's responsibility, by country and wave

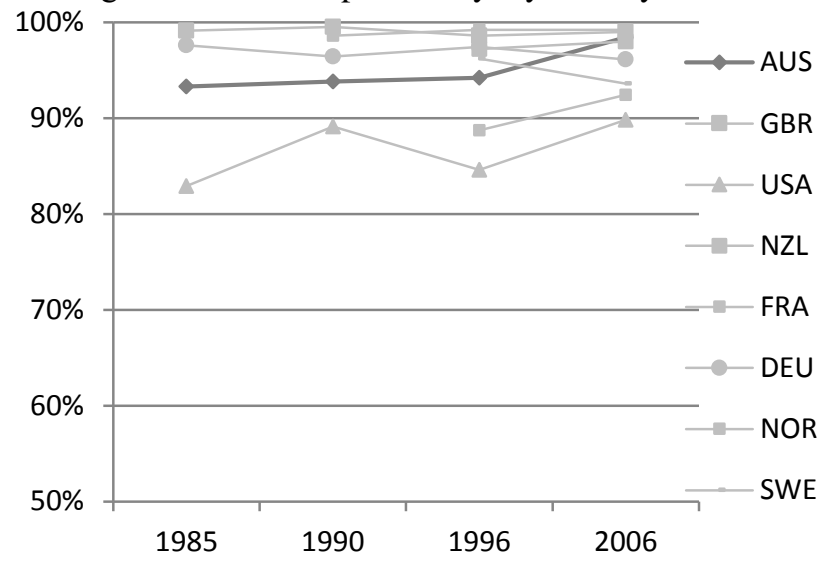

Source: ISSP RoG I-IV (ISSP Research Group, 2008).

Attitudes towards collective social policy that guards against unemployment risks, however, are much more variable. Nearly one-half of all Australians claimed that the government should not be responsible for providing decent living standards for unemployed people in all four waves of the RoG module (Figure 3). A similar picture emerges in the USA. However, in the UK and New Zealand, solidarity with unemployed citizens has declined over the last twenty years, with one-half of the public surveyed now saying that the government should not be responsible for the living standards of unemployed people. Much has been written 
about Australasian and American exceptionalism in social policy. Most of this literature focuses on the individualistic nature of liberal society influencing welfare state architecture and the development of the wage-earning model of welfare in Australia and New Zealand in particular (Castles, 1985). Workfare policies and other regulatory labour market programmes that undermine collective solidarity also have a long history in the USA, where public support for the principles of collective security is found to be at its lowest in the study sample. In Australia, the key shift to activation came much later in the 1990s, when successive administrations pursued strict work-conditionality policies in an effort to cut unemployment and spending on social programmes (Harris, 2001).

Figure 3. Decent living standard for unemployed people: Percentage claiming

it should be the government's responsibility, by country and wave

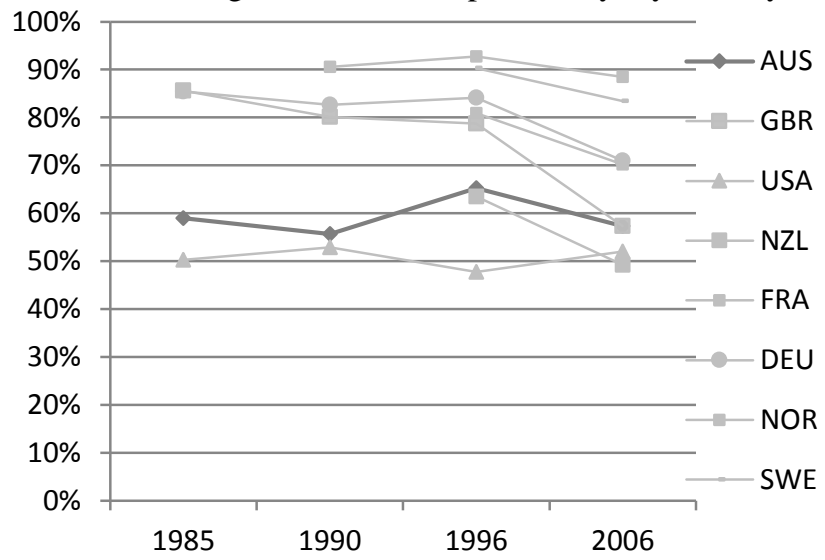

Source: ISSP RoG I-IV (ISSP Research Group, 2008).

Universalistic solidarity for the working population emerges most strongly in the coordinated market economies of Northern and Continental Europe. In Nordic countries, for example, less than one-fifth of the public responding to the latest survey objected to governmental action to protect the living standards of unemployed workers: only 10 percent did so in Norway (Figure 3). In the Bismarkian nations, we find less solidarity for workers, compared 
to the Nordics, but even so, no more than one-third of citizens in France and Germany reject governmental action to protect workers from unemployment risks. By contrast, in Australia and other liberal market economies, there is currently little or no public consensus on the role of government in relation to unemployment protection (Figure 3) and labour market policy (Figure 4). In the latest survey, the Australian public remains divided: 57 percent of Australians support the merits of collective provision for income maintenance to safeguard and protect citizens against unemployment risk, while 43 percent of Australians now favour self-insurance or some other form of individual adaptation to the new social risks imposed by labour market flexibility.

Over the four survey waves, Australians also appear divided on the issue of state intervention in the labour market to ensure that everyone has a job (Figure 4). In the latest survey, for example, 57 percent of Australians claim that it is not the state's duty to ensure that everyone has a job; 43 percent say that it is. The 'role of government' survey question about 'providing a job for everyone' specifically relates to far-reaching actions like 'full employment' policies, most clearly articulated in Australia in the 1940s (Harris, 2001). ${ }^{3}$ From 1945, economic policy under the Curtin-led Labor government followed Keynesian principles, the Keynesian 'economic state'. Thus, the value of investment was to be moderated by the government in order to maintain the economy in a full state of employment (Labor policy from 1945). During the 1980s and 1990s, Australia, like most other developed countries, experienced a neoliberal backlash against state intervention in the market. The Hawke Labor government (1983-91) abandoned the goal of full employment in the face of globalizing forces and increasing world trade. Like its international counterparts, the Australian Labor Party is now content to pursue the (diminished) goal of full employability, as opposed to full employment. 
Figure 4. Jobs for everyone: Percentage claiming it should not be the government's responsibility, by country and wave

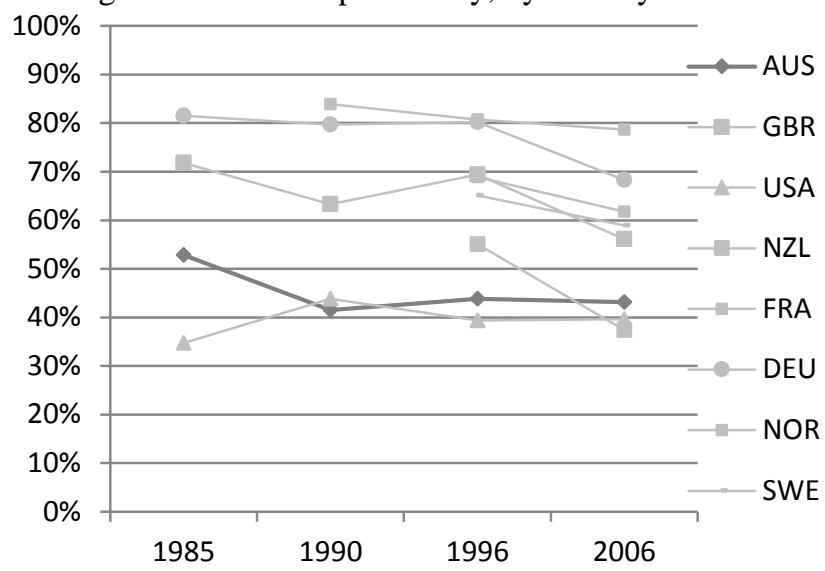

Source: ISSP RoG I-IV (ISSP Research Group, 2008).

In the liberal group of nations as a whole, we find that negative public attitudes towards stateled job-creation schemes have been constant over all four of the survey waves. Policy design, historical institutions and discourse can shape public attitudes. In other words, the liberal model of welfare state capitalism (based on strong elements of individualism, the commodification of labour, free markets and a minimum of state interference) provides feedback effects that impact on public attitudes. The level of state investment in human capital policies and active labour market programmes (ALMPs) in Australia and the other liberal market economies have a dominant laissez-faire ideology remains relatively low by comparison to the coordinated market economies of Northern and Continental Europe and their effectiveness to generate successful employment outcomes in the Australian context is questionable (OECD, 2013). ${ }^{4}$ By contrast, full employment policies and state-led job-creation schemes are strongly favoured in the coordinated market economies of Northern and Continental Europe (Figure 4). As Esping-Andersen (1990) observes, the universalistic Nordic model of welfare depended entirely on employment maximization and the state therefore played a key role in securing this goal, implementing ALMPs to ensure people had work. Policy feedback effects appear to reinforce support for the status quo (Svallfors, 
2006). The strongest level of support for state-led job-creation is found in Norway, where about four-fifths of the population surveyed believe that the state should ensure unemployed

workers have jobs (Figure 4). Not far behind Norway come the corporatist economies of France and Germany, both of whom have strong ALMP traditions (Lodemel and Moreira, 2014). In these countries, most citizens surveyed claim that the state does have a legitimate responsibility to act as the employer of last resort. Citizens in the liberal market economies, however, appear increasingly sceptical about this form of governmental action (Figure 4).

In summary, we find remarkable agreement cross-nationally on the functions of state welfare to ensure decent living standards in old age and healthcare for the sick. Even in the liberal market economies, there is close to universal support for such statutory interventions. At the same time, we find that public support for the range of governmental actions to protect workers from unemployment risks is now divided in Australia and the other liberal welfare states, thus revealing substantial cross-national variation. In the next section, we focus the analysis in an attempt to explain this variation in attitudes. In particular, we seek to model heterogeneity explicitly to shed new light on welfare state attitudes defined by sociodemographic characteristics, including, of course, class-attitudes linkages.

\section{Multivariate results}

In the next step, regression models are used to explain or predict public attitudes towards labour market policy and attitudes towards social protection for workers. Many people in Australia oppose governmental actions to support workers (Figures 3 and 4). Nevertheless, some sections of Australian society may be more critical of state intervention than others. Here we want to identify more clearly those Australians who either are in favour of or are 
against collective forms of social policy to protect the living standards of unemployed women and men and those Australians that agree or disagree with state intervention in the labour market to ensure working-age citizens have jobs.

Beginning with the results in Table 4 relating to the question about governmental action to provide unemployed people with decent living standards, we find a class effect in the Australian data (model 1). In Australia, low-skilled manual workers are significantly more inclined to support collective social policy to guard against unemployment risks than middleclass professionals. The observed class effects are more pronounced in the cross-national sample, however. In that sample, skilled workers are also more likely to favour collective solutions to help mitigate risk (model 2). Partisanship helps to account for Australian welfare state attitudes. Australians with political allegiances on the left, for instance, are significantly more likely to be in favour of supporting state intervention to secure decent living standards for unemployed workers than citizens who vote for parties on the right (model 1, Table 4). Other things being equal, Labor voters in Australia have three times the odds of reporting that the state has a duty to ensure decent living standards for unemployed workers compared to those voters on the right. 
Table 4. Public attitudes towards unemployment protection policy (results from the multivariate logistic regression analysis)

\begin{tabular}{|c|c|c|c|c|c|c|}
\hline \multicolumn{7}{|c|}{ Government responsibility to provide decent living standards for unemployed workers (comparator: not state responsibility) } \\
\hline & \multicolumn{3}{|c|}{$\begin{array}{l}\text { (Model 1) } \\
\text { Australian sample }\end{array}$} & \multicolumn{3}{|c|}{$\begin{array}{l}\text { (Model 2) } \\
\text { Cross-national sample }\end{array}$} \\
\hline & $b$ & SE & Exp & $\mathrm{b}$ & $\begin{array}{l}\text { Shlutor } \\
\text { SE }\end{array}$ & Exp \\
\hline Constant & -0.40 & 0.22 & & 0.28 & 0.12 & \\
\hline \multicolumn{7}{|l|}{ Age (comparator: 15-24) } \\
\hline $25-44$ & 0.26 & 0.19 & 1.30 & 0.01 & 0.09 & 1.01 \\
\hline $45-54$ & 0.56 & 0.20 & $1.75^{* *}$ & 0.17 & 0.09 & 1.19 \\
\hline $55-64$ & 0.66 & 0.21 & $1.94 * * *$ & 0.35 & 0.10 & $1.42 * * *$ \\
\hline $65-74$ & 0.71 & 0.24 & $2.03^{* *}$ & 0.32 & 0.12 & $1.38 * *$ \\
\hline $75+$ & 1.10 & 0.29 & $2.99 * * *$ & 0.51 & 0.14 & $1.66^{* * * *}$ \\
\hline \multicolumn{7}{|l|}{ Gender (comparator: Male) } \\
\hline Female & 0.15 & 0.09 & 1.16 & 0.20 & 0.05 & $1.23 * * * *$ \\
\hline \multicolumn{7}{|l|}{ Education (comparator: Degree) } \\
\hline Below Degree & 0.59 & 0.18 & $0.56^{* *}$ & -0.19 & 0.09 & $0.82^{*}$ \\
\hline No qualifications & 0.39 & 0.11 & $0.68 * * *$ & -0.13 & 0.06 & $0.87 *$ \\
\hline \multicolumn{7}{|c|}{ EGP social class (comparator: Professional) } \\
\hline Salaried white-collar worker & 0.07 & 0.11 & 1.08 & 0.04 & 0.05 & 1.04 \\
\hline Skilled manual worker & 0.03 & 0.16 & 1.03 & 0.16 & 0.08 & $1.18^{*}$ \\
\hline Low-skilled manual worker & 0.00 & 0.16 & $1.27 *$ & 0.25 & 0.08 & $1.29 * * *$ \\
\hline \multicolumn{7}{|c|}{ Labour force status (comparator: Employed) } \\
\hline Economically inactive & 0.01 & 0.39 & 0.99 & 0.94 & 0.18 & $2.57 * * *$ \\
\hline Unemployed & 0.35 & 0.13 & $1.42 * *$ & 0.19 & 0.07 & $1.21 * *$ \\
\hline \multicolumn{7}{|c|}{ Political Party Allegiance (comparator: Right) } \\
\hline Centre & 1.00 & 0.09 & $2.72 * * *$ & 0.47 & 0.06 & $1.60 * * * *$ \\
\hline Left & 1.10 & 0.22 & $2.99 * * *$ & -0.48 & 0.06 & $1.62 * * *$ \\
\hline \multicolumn{7}{|l|}{ Year (comparator: 1996) } \\
\hline 2006 & -0.27 & 0.10 & $0.76^{* * *}$ & -0.37 & 0.05 & $0.69^{* * * *}$ \\
\hline \multicolumn{7}{|l|}{ Country (comparator: AUS) } \\
\hline USA & - & - & - & -0.22 & 0.11 & $0.80^{*}$ \\
\hline GBR & - & - & - & -0.44 & 0.07 & $0.64^{* * * *}$ \\
\hline NZL & - & - & - & -0.08 & 0.09 & 0.92 \\
\hline DEU & - & - & - & 0.77 & 0.08 & $2.15^{* * * *}$ \\
\hline FRA & - & - & - & 0.69 & 0.07 & $2.00^{* * * *}$ \\
\hline NOR & - & - & - & 1.98 & 0.10 & $7.21 * * *$ \\
\hline SWE & - & - & - & 1.27 & 0.11 & $3.55^{* * * *}$ \\
\hline \multicolumn{7}{|l|}{ Interactions } \\
\hline Manual worker 1996 x 2006 & -0.04 & 0.29 & 0.96 & -0.28 & 0.12 & $0.76^{*}$ \\
\hline White-collar worker 1996 × 2006 & -0.48 & 0.16 & $0.62 * *$ & -0.31 & 0.07 & $0.73^{* * * *}$ \\
\hline Left voter 1996 x 2006 & -0.09 & 0.14 & 0.91 & -0.32 & 0.07 & $0.73 * * * *$ \\
\hline Nagelkerke R-Square & 0.10 & & & 0.20 & & \\
\hline
\end{tabular}

Notes: Significance levels: $*<0.05 ; * *<0.01 ; * * *<0.001$.

There are strong age gradients in the Australian survey data, which are also observed in the cross-national results, model 2. Older adults are more likely than younger adults (aged 1524) to support state intervention to secure decent living standards for unemployed workers, after controlling for all other factors. Surprisingly, perhaps, there is no gender effect in the Australian data, whereas women are much more likely than men to support government action in the cross-national sample (which is consistent with other findings in this field, Jæger, 2007). Education is an important predictor of welfare state attitudes in Australia. A 
person educated to university degree level is significantly more likely to believe in collective security to protect the living standards of unemployed citizens, compared to people with educational attainment below degree level. Unsurprisingly, unemployed Australians who have the highest use of state benefits tend to be most supportive of social policy, compared to citizens in the employed category. Other things being equal, the odds of an unemployed worker claiming the state should guarantee them a decent living standard are 42 percent greater than the odds for a citizen in paid employment. Governmental action to combat the adverse effects of unemployment is clearly of value to those citizens who are protected by the social policy. Importantly, the data suggest that support for collective solutions to help mitigate unemployment risks has significantly declined in Australia over the past decade, particularly amongst white-collar workers. In general, Australians are more pro-welfare than citizens in the other market liberal economies of the USA and the UK (note that the difference with New Zealand is non-significant, model 1, Table 4). The highest levels of public support for governmental action are to be found in the Nordic nations. At the extremes, for example, the odds of a Norwegian citizen claiming that the state should provide decent living standards for unemployed women and men are about seven times greater compared to an Australian citizen (model 1, Table 4). In other words, the odds of a Norwegian favouring governmental intervention are five-hundred-and-eighty-three percent greater than the average Australian, after controlling for all other factors.

Next, we turn to views on government action to ensure all workers have jobs (Table 5). Here we find strong class effects in the Australian data (model 1). In Australia, workingclass representatives are much more inclined to support state action to ensure jobs than middle-class citizens. Other things being equal, the odds of low-skilled manual workers supporting government intervention in favour of the unemployed are 52 percent higher than for professionals (observed in model 1, Table 5). Furthermore, the odds of an unemployed 
worker claiming that the state has a duty to ensure jobs for all Australian workers are 28 percent greater than for an Australian who is in paid employment, after controlling for all other factor. Labor voters in Australia are also significantly more likely to be in favour of government intervention to solve the problem of unemployment compared to voters on the right (model 1, Table 5). Other things being equal, Labor voters have over twice the odds of saying that the state has a duty to ensure jobs for unemployed Australians compared to voters on the right.

Table 5. Public attitudes towards full employment policy (results from the multivariate logistic regression analysis)

\begin{tabular}{|c|c|c|c|c|c|c|}
\hline \multicolumn{7}{|c|}{ Government responsibility to provide jobs for unemployed workers (comparator: not state responsibility) } \\
\hline & \multicolumn{3}{|c|}{$\begin{array}{c}\text { (Model 1) } \\
\text { Australian sample }\end{array}$} & \multicolumn{3}{|c|}{$\begin{array}{c}\text { (Model 2) } \\
\text { Cross-national sample }\end{array}$} \\
\hline & $\mathrm{b}$ & SE & Exp & $\mathrm{b}$ & SE & Exp \\
\hline Constant & -0.76 & 0.22 & & -0.49 & 0.12 & \\
\hline \multicolumn{7}{|l|}{ Age (comparator: 15-24) } \\
\hline $25-44$ & -0.36 & 0.19 & 0.70 & -0.44 & 0.09 & $0.65^{* * * *}$ \\
\hline $45-54$ & -0.33 & 0.20 & 0.72 & -0.57 & 0.09 & $0.57 * * * *$ \\
\hline $55-64$ & -0.41 & 0.21 & $0.66^{*}$ & -0.64 & 0.10 & $0.53^{* * * *}$ \\
\hline $65-74$ & -0.47 & 0.24 & 0.63 & -0.62 & 0.11 & $0.54 * * * *$ \\
\hline $75+$ & -0.22 & 0.28 & 0.81 & -0.71 & 0.14 & $0.49^{* * * *}$ \\
\hline \multicolumn{7}{|l|}{ Gender (comparator: Male) } \\
\hline Female & 0.33 & 0.09 & $1.39 * * *$ & 0.38 & 0.04 & $1.46^{* * * * *}$ \\
\hline \multicolumn{7}{|l|}{ Education (comparator: Degree) } \\
\hline Below Degree & 0.03 & 0.19 & 1.03 & 0.55 & 0.08 & $1.74 * * * *$ \\
\hline No qualifications & -0.11 & 0.11 & 0.90 & 0.19 & 0.06 & $1.21 * * * *$ \\
\hline \multicolumn{7}{|c|}{ EGP social class (comparator: Professional) } \\
\hline Salaried white-collar worker & 0.11 & 0.11 & 1.12 & 0.28 & 0.05 & $1.32 * * * *$ \\
\hline Skilled manual worker & 0.33 & 0.16 & $1.39 *$ & 0.46 & 0.07 & $1.58 * * * *$ \\
\hline Low-skilled manual worker & 0.42 & 0.16 & $1.52 * *$ & 0.74 & 0.07 & $2.09 * * *$ \\
\hline \multicolumn{7}{|c|}{ Labour force status (comparator: Employed) } \\
\hline Economically inactive & 0.45 & 0.38 & 1.57 & 0.46 & 0.15 & $1.58 * * *$ \\
\hline Unemployed & 0.25 & 0.12 & $1.28 *$ & 0.22 & 0.06 & $1.25^{* * * *}$ \\
\hline \multicolumn{7}{|c|}{ Political Party Allegiance (comparator: Right) } \\
\hline Centre & 0.86 & 0.09 & $2.37 * * *$ & 0.50 & 0.06 & $1.65^{* * * *}$ \\
\hline Left & 0.83 & 0.20 & $2.29 * * *$ & -0.30 & 0.06 & $0.74 * * *$ \\
\hline \multicolumn{7}{|l|}{ Year (comparator: 1996) } \\
\hline 2006 & -0.07 & 0.10 & 0.94 & -0.25 & 0.05 & $0.78^{* * * *}$ \\
\hline \multicolumn{7}{|l|}{ Country (comparator: AUS) } \\
\hline USA & - & - & - & 0.34 & 0.11 & $1.40 * * *$ \\
\hline GBR & - & - & - & -0.19 & 0.07 & $0.83^{* * * *}$ \\
\hline NZL & - & - & - & 0.22 & 0.09 & $1.25^{* * * *}$ \\
\hline DEU & - & - & - & 0.97 & 0.07 & $2.62 * * *$ \\
\hline FRA & - & - & - & 0.94 & 0.07 & $2.55^{* * * *}$ \\
\hline NOR & - & - & - & 1.76 & 0.08 & $5.83^{* * * *}$ \\
\hline SWE & - & - & - & 0.61 & 0.09 & $1.85^{* * * *}$ \\
\hline \multicolumn{7}{|l|}{ Interactions } \\
\hline Manual worker 1996 x 2006 & -0.16 & 0.29 & 0.85 & -0.15 & 0.12 & 0.86 \\
\hline White-collar worker 1996 × 2006 & -0.05 & 0.16 & 0.95 & -0.23 & 0.07 & $0.80 * * *$ \\
\hline Left voter 1996 x 2006 & -0.06 & 0.13 & 0.94 & -0.38 & 0.06 & $0.68^{* * * *}$ \\
\hline Nagelkerke R-Square & 0.08 & & & 0.20 & & \\
\hline
\end{tabular}

Notes: Significance levels: $*<0.05 ; * *<0.01 ; * * *<0.001$. 
Despite high unemployment rates amongst young people in Australia at twice the national average (OECD, 2012b), there is little evidence of an age effect in the Australian survey data (model 1). With youth unemployment rates in the advanced economies at record levels young people (aged 15-24) in the cross-national sample, by contrast, are significantly more likely to support state intervention to ensure everyone has jobs than respondents in all other age groups (model 2). Such findings are not altogether surprising. However, the age effect appears absent in Australia. Women in Australia are significantly more likely to support state action to ensure jobs than men. Education is an important predictor of attitudes in the crossnational sample but not in the Australian data. In the general sample, a person with educational attainment below degree level is significantly more likely to believe in governmental action to ensure everyone has a job. There has been little overall change in Australian attitudes over the last decade and no significant change in attitudes defined by either class or partisanship. According to the survey results, Australians are much less inclined to support state intervention in the labour market to ensure workers have jobs than citizens in all of the other countries except the UK (observed in model 2). The highest levels of public support for governmental action are to be found in the coordinated economies of Northern and Continental Europe. For example, the odds of a Norwegian citizen claiming that the state should ensure all workers have jobs are about six times greater compared to an Australian citizen. In other words, the odds of a Norwegian favouring governmental action to ensure jobs is five-hundred-and-eighty-three percent greater than the average Australian, after controlling for all other factors.

The results from the regression analysis can be used to estimate the relative odds of favouring collective social policy for representative citizens in each social class (by country) in order to understand more about class-based welfare attitudes. We saw above that Australians are more in favour of collective solutions to protect the living standards of 
unemployed people compared to citizens in the other liberal countries. Now we are able to understand more about the classed effects in the survey data. The results for manual workers in Table 6 are particularly interesting. Low-skilled manual workers are most likely to experience precarious employment and periods of unemployment compared to representatives from the other social classes, so their attitudes towards collective social policy are particularly relevant here. Amongst the liberal countries, low-skilled workers in Australia are most likely to favour governmental action to protect the living standards of unemployed workers. For example, low-skilled female workers aged 25-44 in Australia have over twice the odds of saying the state should act to protect the living standards of unemployed workers, compared to low-skilled female workers in the same age group in both Britain and New Zealand (Table 6). We find that the odds of an Australian low-skilled female worker favouring governmental action to protect workers are now three times greater compared to the same worker in the United States, after controlling for everything else. In fact, lowskilled manual workers in Australia are as likely to favour social policy protection as lowskilled manual workers in the corporatist systems of Germany and France, where capitallabour arrangements (including workers' unions) look to secure cooperation among the classes in order to create decent living standards for labourers. Only in the Nordic nations do we find stronger support amongst manual workers for governmental action to protect the living standards of unemployed people, compared to Australia (Table 6). There is less crossnational variation in support for collective security amongst middle-class professionals and while-collar workers, except for Norway and perhaps Sweden, where solidarity emerges most strongly in the survey data. For example, a low-skilled Norwegian female worker aged 25 years is now sixteen times more likely to be in favour of social welfare, compared to the equivalent Australian. The equivalent odds for a man are about 15-1. 
Table 6. Odds of reporting the state is responsible for providing a decent standard of living for unemployed people - defined by age, gender, class, and citizenship

\begin{tabular}{|lllllllllll|}
\hline Age & Gender & EGP class & AUS & GBR & USA & NZL & FRA & DEU & NOR & SWE \\
$25-44$ & Male & Professional & 1.42 & 0.95 & 0.77 & 1.10 & 2.56 & 2.38 & 8.58 & 4.22 \\
$"$ & Female & " & 1.64 & 1.02 & 0.82 & 1.18 & 2.76 & 2.56 & 9.24 & 4.55 \\
$"$ & Male & Salaried white-collar & 2.11 & 1.16 & 0.94 & 1.34 & 3.13 & 2.90 & 10.48 & 9.06 \\
$"$ & Female & $"$ & 2.52 & 1.27 & 1.02 & 1.46 & 3.42 & 3.17 & 11.44 & 5.63 \\
$"$ & Male & Skilled manual & 2.80 & 1.34 & 1.08 & 1.54 & 3.60 & 3.34 & 12.06 & 5.94 \\
$"$ & Female & " & 3.24 & 1.44 & 1.16 & 1.66 & 3.88 & 3.60 & 12.98 & 6.39 \\
$"$ & Male & Low-skilled manual & 4.17 & 1.63 & 1.31 & 1.88 & 4.40 & 4.08 & 14.72 & 12.74 \\
$55-64$ & Male & Professional & 4.97 & 1.78 & 1.44 & 2.05 & 4.80 & 4.45 & 16.08 & 7.91 \\
$"$ & Female & " & 1.23 & 0.63 & 0.51 & 0.73 & 1.71 & 1.58 & 5.72 & 2.81 \\
$"$ & Male & Salaried white-collar & 1.50 & 1.09 & 0.88 & 1.25 & 2.93 & 2.72 & 9.81 & 8.49 \\
$"$ & Female & $"$ & 1.64 & 1.19 & 0.96 & 1.37 & 3.20 & 2.97 & 10.71 & 5.27 \\
$"$ & Male & Skilled manual & 1.73 & 0.89 & 0.72 & 1.03 & 2.40 & 2.23 & 8.04 & 3.96 \\
$"$ & Female & " & 1.86 & 0.68 & 0.55 & 0.79 & 1.84 & 1.70 & 6.16 & 3.03 \\
$"$ & Male & Low-skilled manual & 2.11 & 0.77 & 0.62 & 0.89 & 2.08 & 1.93 & 6.98 & 6.04 \\
$"$ & Female & " & 2.31 & 0.84 & 0.68 & 0.97 & 2.28 & 2.11 & 7.62 & 3.75 \\
\hline
\end{tabular}

Notes: ${ }^{2}$ Reference category: Professional male aged 15-24 in Australia.

\section{Australian attitudes to unemployment and unemployed people}

So how might we explain the Australian results? There is strong support for universal welfare amongst low-skilled manual workers in Australia, while support for selective social policy is increasing amongst middle-class voters. The findings point to the continued relevance of class in contemporary society. Risk society has not dissipated the relevance of class to one's life chances and distribution of risks. Class continues to be a crucial factor influencing beliefs about the functions of the welfare state at a time when the emphasis of social policy is no longer exclusively about the protection of working-class families within the capitalist state. In the battle over the political middle ground, middle-class families have been brought into the social security system through the mechanisms of tax rebates and credits. Thus, while minimum wage schemes and working tax credits have helped to ensure the welfare system always makes work pay, we find that wage replacement rates are relatively low and have 
fallen in real terms. In 2005, for example, benefit replacement rates, paid in the initial phase of unemployment, for an adult stood at 33 percent of average wages compared to just 23 percent in 2011 - a 10 percent fall against average earnings (OECD, 2012a). Thus, Australians appear to accept the risk of a relatively low standard of living if they are unable to work or become unemployed. Benefit levels in Australia continue to be amongst the lowest in the Western world; only unemployed adults in the UK receive less (OECD, 2012a).

\section{Discussion}

Leaving aside for the moment questions about the reliability of the cross-national survey data underpinning the analyses, we find that the traditional functions of the welfare state (that ensure decent living standards in old age and healthcare for the sick) have not lost relevance in Australia. Attitudes towards working-age welfare and government strategies addressing the problem of unemployment are more polarized in Australia, however. The analysis suggests that dominant welfare state ideology continues to matter. In general, support for social policy emerges most strongly in the Nordic world, while people in the liberal market economies show less positive attitudes towards collective unemployment protection and state intervention in the labour market to ensure all workers have jobs. The Bismarkian nations are somewhere in between. From the analysis reported here, it appears that solidarity with unemployed workers has declined in the liberal world across all four RoG waves. Nevertheless, declines in welfare solidarity in the coordinated market economies of Europe have been relatively modest in comparison to the market liberal states. Many Australians oppose the unconditional welfare state model that provides social security for unemployed workers, a finding which is consistent with other national attitudinal surveys (Eardley and 
Matheson, 1999; Wilson and Meagher, 2007). Our current analysis enriches the discourse by revealing some of the class-based contours in a comparative fashion.

Work has long been regarded as the best way to secure well-being for Australian families. The 2009 Henry Review of the tax system revealed little political appetite for an expanded system of welfare paid out of general taxation or out-of-work benefits set at more generous levels. Thus, Australians appear to accept the risk of a relatively low standard of living if they are unable to work or become unemployed. Instead, policymakers have sought to maximise employment by securing acceptable conditions of work, including legislative measures to ensure a fair minimum wage for workers. Being out of work and claiming benefits from the state have increasingly been defined by policymakers as being problematic; dependency is not only detrimental to the moral character of the claimant, but, it is claimed, it also erodes the moral life of society more generally. Unemployed workers are said to be making claims on society's scarce resources, while contributing little, if anything, back to society. As a consequence, work conditionality and regulatory workfare measures appear to have found a new level of legitimacy in Australian society at the start of the 21 st century. While community work programmes and the new sanctions regime introduced by the LiberalNational coalition government are still in their infancy, we do not know what impact, if any, the new right-wing policies will have on people's attitudes and values. Under the coercive new workfare programmes, the state is increasingly prepared to make 'jobseekers' 'work for the dole' in order to discipline unemployed people. Clearly, workfare marks a retreat of the welfare state, as workfare arrangements undermine social rights and deter welfare claims, as Harris (2001) observes. If Australians accept the principles underpinning these policies, we might expect further declines in public support for the unconditional welfare model that helps to mitigate workers' exposure to unemployment risk when the RoG survey module is next repeated in Australia in 2016. 
According to the results, solidarity with the working class is weakening in Australia and the other market liberal economies. However, low-skilled workers who experience greater job insecurity have a strong desire to see the welfare safety net more securely woven to protect their living standards in the event of unemployment. Socio-economic position therefore matters when it comes to welfare state attitudes. Manual workers are also more likely than middle-class professionals to favour governmental action to ensure everyone has a job. Significantly, however, support for these particular welfare state functions has declined in Australia over the past decade, particularly amongst white-collar workers. Australians who are more affluent appear to be adopting a tougher line on welfare and are less willing to accept or share collective responsibility for unemployment risks than they once were. It appears that white-collar voters are adapting to the activation measures that were put in place in the 1990s. In Australian social policy terms, Labor's 1994 White Paper, Working Nation, represented a radical ideological departure from the traditional role of social security, which had hitherto focused on redistributing provisions to support those without work. Whether this downward trend will continue remains to be seen. Will we see further declines in support for collective social policy that guards against unemployment risks, as more affluent citizen's look to minimise their own personal risk exposures at the expense of others? Will class antagonisms appear more or less pronounced when the RoG survey is repeated?

\section{Cautions and further research}

This study examined Australian welfare state attitudes in a comparative perspective, with particular attention to the class-attitudes nexus. We utilized a cross-national collaboration of ISSP data spanning four survey waves and a multivariate regression analysis. A number of cautions and suggestions for further research follow. 
Firstly, we need to know whether (or the extent to which) the RoG is capturing or reflecting real and deep-seated value changes in Western societies. Qualitative inquiry is likely to help in this respect. Often, social surveys (like the RoG) are interested only in responses to welfare or social services as if they applied only to others. We actually need to know what kinds of income security people actually want for themselves and their dependents. We also need to know why social security should apply only to older people in the liberal market economies. In other words, we need a deeper understanding of why people in different welfare states view the 'deserving needy' in different ways: why are unemployed people in Norway seen as 'deserving' but not those in Australia, for example? Qualitative research might also consider the ways in which working class and middle class representatives set about designing their own social policies to cover unemployment risks and the interaction between the public and private spheres of decision-making, covering insurances, private pensions and other risk-based income maintenance plans.

Secondly, the RoG module focuses on the 'direct' job-creation aspect of labour market policy, providing reliable attitudinal trend data on state job-creation strategies from the four survey waves. However, while spending on direct job-creation still accounts for the largest component of ALMP spending in the OECD, it is in decline, and spending on 'employment incentives' for employers is increasing (OECD, 2013). Shifting political priorities are particularly important with the more radical US-style workfare programmes gaining momentum in the Anglo-World. In future rounds, therefore, the RoG might look to probe public attitudes to ALMPs more closely, including views on the use of employer incentives and public investment in training programmes.

Finally, national panel surveys might be analysed to shed more light on the views of those individuals who have changed or modified their own views about the role of government over time. Repeated cross-sectional survey data from the RoG allows attitudes to be estimated 
only at the aggregate level. That is, the attitude of each individual is only measured at one point in time, meaning that any individual change in attitude cannot be captured.

\section{Endnotes}

${ }^{1}$ In the early rounds, occupational coding is country-specific, as national statistical agencies employed their own class schemes in the survey.

${ }^{2}$ The (pseudo) R-statistic in logistic regression should not be interpreted exactly like R-square in OLS (ordinary least-squares) regression, here Nagelkerke R-Squares over 0.2 are considered highly satisfactory, particularly in large cross-national samples.

${ }^{3}$ Far-reaching governmental actions and policies for promoting full employment should not be confused with the coercive processes now employed by the Australian (workfare) state, whereby jobseekers must now undertake community work in exchange for benefits.

${ }^{4}$ In 2011, for example, public expenditure on ALMPs in Denmark was 2.3 percent of GDP compared to just 0.3 percent in Australia.

\section{References}

Beck, U. and E. Grande (2010) 'Varieties of second modernity: the cosmopolitan turn in social and political theory and research', The British Journal of Sociology 61: 409443.

Castles, F. G. (1985) The working class and welfare: reflections on the political development of the welfare state in Australia and New Zealand, 1890-1980. Wellington: Allen \& Unwin.

Curran, D. (2013) 'Risk society and the distribution of bads: theorizing class in the risk society', The British Journal of Sociology 64: 44-62.

Eardley, T. and G. Matheson (1999) Australian Attitudes to Unemployment and Unemployed People. SPRC Discussion Paper No. 102, Sydney: Social Policy Research Centre, University of New South Wales.

Esping-Andersen, G. (1990) The Three Worlds of Welfare Capitalism: Cambridge: Polity Press and Princeton, NJ: Princeton University Press.

Ganzeboom, H. B. G., P. M. De Graaf, D. J. Treiman and J. De Leeuw (1992) 'A Standard International Socio-Economic Index of Occupational Status', Social Science Research 21: $1-56$.

Haddon, E. (2014) 'Class identification in New Zealand: An analysis of the relationship between class position and subjective social location', Journal of Sociology Published online before print, DOI: 10.1177/1440783314530529.

Haller, M., R. Jowell and T. W. Smith (2012) The International Social Survey Programme 1984-2009: Charting the Globe. London: Routledge.

Harris, P. (2001) 'From relief to mutual obligation: welfare rationalities and unemployment in 20th-century Australia', Journal of Sociology 37: 5-26.

Hosmer, D. W. and S. Lemeshow (2000) Applied Logistic Regression. Second Edition. New York: John Wiley \& Sons. 
ISSP Research Group (2008) International Social Survey Programme: Role of Government IIV - ISSP 1985-1990-1996-2006. Cologne: GESIS Data Archive, ZA4747 Data file Version 1.0.0, DOI: 10.4232/1.4747.

Jæger, M. M. (2007) 'Are the 'deserving needy' really deserving everywhere? Cross-cultural heterogeneity and popular support for the old and the sick in eight Western countries', pp. 73-94 in S. Mau and B. Veghte (eds.) Social Justice, Legitimacy and the Welfare State. Aldershot: Ashgate.

Jæger, M. M. (2011) 'Do we all (dis)like the same welfare state? Configurations of public support for the welfare state in comparative perspective', pp. 45-68 in J. Kvist, J. Fritzell, B. Hvinden and O. Kangas (eds.) Changing Social Equality: The Nordic Welfare Model in the 21st Century. Bristol: Policy Press.

Keune, M. and A. Serrano, (eds.) (2014) Deconstructing Flexicurity and Developing Alternative Approaches: Towards New Concepts and Approaches for Employment and Social Policy. New York, Routledge.

Leiulfsrud, H., I. Bison and E. Solheim (2010) Social Class in Europe II: The European Social Survey 2002-2008. Trondheim: NTNU.

Lodemel, I. and A. Moreira, (eds.) (2014) Activation or Workfare? Governance and the NeoLiberal Convergence. Oxford and New York, NY, Oxford University Press.

OECD (2012a) Benefits and Wages. Paris: OECD Publishing http://www.oecd.org/els/benefitsandwagesstatistics.htm.

OECD (2012b) Youth unemployment rate 2012. OECD Publishing 10.1787/unemp-yth-table2012-1-en.

OECD (2013) Public expenditure on active labour market policies. Employment and Labour Markets: Key Tables from OECD, No. 9: DOI: 10.1787/lmpxp-table-2013-1-en.

Papadakis, E. (1990) 'Conjectures about Public Opinion and the Australian Welfare State', Journal of Sociology 26: 209-234.

Svallfors, S. (1997) 'Worlds of Welfare and Attitudes to Redistribution: A Comparison of Eight Western Nations', European Sociological Review 13: 283-304.

Svallfors, S. (2006) The Moral Economy of Class: Class and Attitudes in Comparative Perspective. Stanford CA: Stanford University Press.

Wilson, S. and G. Meagher (2007) 'Howard's Welfare State: How Popular is the New Social Policy Agenda', pp. 262-285 in D. Denemark, G. Meagher, S. Wilson, M. Western and T. Phillips (eds.) Australian Social Attitudes 2: Citizenship, Work and Aspirations. Sydney: UNSW Press. 